\title{
Molecular Profiles and Antimicrobial Susceptibility of First Isolates of Streptococcus agalactiae Serotype IX in Argentina
}

\author{
Margarita Laczeski*, Eduardo Pegels, Patricia Oviedo, Marina Quiroga, Marta Vergara \\ Department of Microbiology, Bacteriology, Faculty of Exact, Chemical and Natural Sciences, National \\ University of Misiones, Posadas, Argentina \\ Email: ${ }^{*}$ melaczeski@fceqyn.unam.edu.ar
}

Received 29 April 2014; revised 29 May 2014; accepted 15 May 2014

Copyright (C) 2014 by authors and Scientific Research Publishing Inc.

This work is licensed under the Creative Commons Attribution International License (CC BY).

http://creativecommons.org/licenses/by/4.0/

(c) (i) Open Access

\begin{abstract}
Streptococcus agalactiae (GBS) is considered as the most important cause of invasive bacterial disease in infants. There are few current data from serotype IX of GBS worldwide. The present work has been done in order to make a contribution to the knowledge of serotype IX through phenotypic and genotypic study of virulence and resistance. Of 200 strains tested, $5.5 \%$ were serotype IX and all were colonizing. In $63.6 \%$ of the strains the presence of the bac, bca and hylB genes was determined, and in $54.5 \%$ of $\operatorname{Imb}$ and $\mathrm{rib}$. All strains were susceptible to Clindamycin and Erythromycin however five isolates showed the resistance genes: ermB, ermTR and/or mefA. The presence of serotype IX in Misiones, a province situated in the northeaster of Argentina, which limits with Paraguay and Brazil in South America, gives the region a particular situation. Currently, public health efforts are aimed at prevention and treatment, study of the virulence mechanisms, surveillance of resistance to antibiotics and the development of effective vaccines to prevent GBS infection.
\end{abstract}

\section{Keywords}

Streptococcus agalactiae Serotype IX, Virulence Genes, Resistance Genes, Clindamycin, Erythromycin

\section{Introduction}

Streptococcus agalactiae, group B streptococcus or commonly called GBS, was initially known as an infective

*Corresponding author.

How to cite this paper: Laczeski, M., Pegels, E., Oviedo, P., Quiroga, M. and Vergara, M. (2014) Molecular Profiles and Antimicrobial Susceptibility of First Isolates of Streptococcus agalactiae Serotype IX in Argentina. Advances in Microbiology, 4, 474-483. http://dx.doi.org/10.4236/aim.2014.48052 
agent affect in gudders of cows from which it received the name of Streptococcus agalactiae [1] [2]. In 1938, it was first described as the cause of human infection in three patients with fatal puerperal sepsis [3] [4]. Today GBS is considered as the most important cause of invasive bacterial disease in infants in which the mother-child vertical transmission plays a leading role [5] [6]. The bacteria colonize the gastrointestinal and genital tract of pregnant women where it can access and cause infection [7] and the transmission from mother to newborn occurs before delivery or after rupture of membranes. The frequency of colonization of newborns of carrier mothers is around $50 \%$ and between $1 \%$ and $2 \%$ developed infection. The vaginal colonization of pregnant is intermittent so crops grown by 5 weeks of delivery are not reliable to predict the state of the carrier at the time of delivery and must be repeated. Our results, obtained from studying, before delivery, 3125 pregnant women between 2004-2008, show a colonization rate of 9.38\% [6]. According to various studies, its incidence has increased since the 1970s, causing not only severe neonatal disease but also infections in pregnant and non-pregnant adults with predisposing chronic diseases [8] [9].

The capsular polysaccharide is one of the most important and best studied virulence factor, and GBS is classified by capsular phenotype in ten identified serotypes: Ia, Ib, and II-IX, based on 10 unique polysaccharide with immunological characteristics associated with virulence and encoded in the capsular gene cluster (cps) [2] [10] and are associated with different surface proteins of antigenic characteristics, such as $\alpha, \beta$, Rib, hylB and lmb, which are encoded by several genes associated with virulence and host interaction acting on bacteria involved in invasiveness [2] [11]. The study of surface protein antigens is important for the understanding of the pathogenesis and epidemiology of infection and several these antigens have been proposed as components of multivalent conjugate vaccines [12].

Currently, efforts are focused on the prevention and treatment, to study virulence mechanisms, surveillance of antibiotic resistance and to develop effective vaccine strategies to prevent GBS infection [5] [13]. Prevention currently relies on the detection of maternal colonization and intrapartum prophylaxis (PIP) performed with penicillin as a drug of choice, by its sensitivity, low cost and few adverse reactions. In patients who are allergic to beta-lactam antibiotics, Erythromycin (ERI) and Clindamycin (CLI) are the drugs of choice [8] [14]. In recent years, an increase in the resistance to these drugs has been reported, so that it becomes increasingly necessary to its epidemiological purposes and monitoring of treatment [6] [14] [15]. The macrolide resistance mechanisms include expression: erm gene encodes a methylase which modifies the target site developing resistance to macrolides, lincosamides and estretograminas $\mathrm{B}$, [phenotype $\mathrm{MLS}_{\mathrm{B}}$-constitutively expressed $\left(\mathrm{cMLS}_{\mathrm{B}}\right)$ or inducible $\left.\left(\mathrm{iMLS}_{\mathrm{B}}\right)\right]$ or the mefA gene that mediates efflux mechanisms that lead to resistance to macrolides of 14 to 15 carbon atoms (M phenotype) [10] [14] [16]. The therapeutic success depends on proper search and interpretation of these phenotypes. The Clinical and Laboratory Standards Institute (CLSI) [17] recommends the use of the double-disk test (D-test) for the detection of their phenotypes and confirmation by Minimum Inhibitory Concentration (MIC). While intrapartum prophylaxis reduces early-onset disease caused by GBS, it has no implication on the late-onset infection. It is crucial to develop antigen-based vaccines and maternal vaccination to prevent neonatal disease [18] [19]. Changes in the epidemiology of GBS have an impact on the development of vaccines, therefore monitoring of the serotypes circulating, antigen expression and resistance is important [20] [21].

There are few current data from serotype IX worldwide since its proposal as new capsular serotype in 2007 [20]-[23]. Throughout America, no notifications of this serotype were reported except from our first findings in Argentina [6]. Other countries in North America and Latin America to date reported serotypes Ia, Ib, II, III, IV and V [14] [24]-[27]. Even the serotypes VI, VII and VIII have been reported in North America but not de IX serotype [25] [28]. In the bibliography, there is little global history of GBS serotype IX isolates identified to date. Argentina does not have previous records and there is even less knowledge of the molecular profile that characterizes their virulence, resistance to antimicrobials and/or its epidemiology. The present work has been done in order to make a contribution to the knowledge of this particular serotype through phenotypic and genotypic study of virulence and resistance in a population of pregnant women in Misiones, a province situated in the northeaster of Argentina, which limits Paraguay and Brazil in South America.

\section{Materials and Methods}

Eleven identified isolates of GBS serotype IX out of 200 randomly selected strains were studied. All recovered from vaginal and rectal swabs from pregnant women with 35 - 37 weeks of gestation and of invasive isolates, in different time periods between 2004 and 2011 and all maintained in $20 \%$ skimmed milk at $-80^{\circ} \mathrm{C}$. All these iso- 
lates were colonizing.

\subsection{Biochemical and Serological Characterization of Group}

Conventional biochemical tests and commercial kits for latex particle agglutination (Phadebact Strep B TestETC-Bactus International AB Sweden) were used to identify those isolates.

\subsection{Determination of Serotype}

Agglutination test of Statens Serum Institute (Strep-B. Latex Copenhagen S. Denmark.), containing ten serotypes (Ia, Ib, II, III, IV, V, VI, VII, VIII and IX) was used to identify all serotypes of GBS.

\subsection{Antimicrobial Susceptibility Testing}

Susceptibility to erythromycin and clindamycin was assessed phenotypically both by the Kirby-Bauer doubledisk diffusion method on Mueller Hinton agar (Biokar, France), supplemented with 5\% of sheep blood [17], which also identifies the constitutive, inducible and M resistance phenotypes [10] [29] and by the E test for MIC determination [ERI = MIC Evaluator OXOID (United Kingdom); CLI = ETEST Clindamycin Biomeriux (France)]. Erythromycin (15 $\mu \mathrm{g})$ and clindamycin $(2 \mu \mathrm{g})$, disks used in the diffusion methods, were provided by Britania (Argentina). S. aureus ATCC 25923 was used as control strain. Results were interpreted according to break points recommended by the CLSI [17]. Break points used for diffusion method double disk and for MIC are shown in Table 1. The results that can be obtained with the D-test and possible phenotypes are shown in Table 2.

\subsection{Genotypic Characterization}

The chromosomal DNA extraction protocol was performed according to Sambrook [30]. The evaluation of the quality and quantity of extracted DNA was performed by agarose gel $1 \%$ electrophoretic stained with ethidium bromide and subsequent observation of the bands in UV transilluminator (MUV Model21-312-220).

Resistance genes were investigated by conventional PCR: ermB (constitutively expressed methylase), ermTR (inducibly expressed methylase) and mefA (efflux mechanism). The Virulence genes studied were those encoding the $\mathrm{C}$ protein (bac and $b c a$ ), Rib protein ( $r i b)$, laminin $(\operatorname{lmb})$ and hyaluronidase (hylB).

Table 1. Zone diameter susceptibility and MIC Interpretative Criteria for Erytromycin (ERI) and (CLI). Taked of Table 2H-1 Streptococcus spp. $\beta$-Hemolytic Group. M02 and M07. CLSI , Vol. 33, Nro 1. January 2013, pp, 114.

\begin{tabular}{|c|c|c|c|c|c|c|c|}
\hline \multirow{2}{*}{$\begin{array}{l}\text { Antimicrobial } \\
\text { Agent }\end{array}$} & \multirow{2}{*}{ Disk content } & \multicolumn{3}{|c|}{$\begin{array}{l}\text { Zone Diameter Interpretative Criteria } \\
\text { (nearest whole } \mathrm{mm} \text { ) }\end{array}$} & \multicolumn{3}{|c|}{ MIC Interpretative Criteria $(\mu \mathrm{g} / \mathrm{mL})$} \\
\hline & & $\mathrm{S}$ & I & $\mathrm{R}$ & $\mathrm{S}$ & I & $\mathrm{R}$ \\
\hline Erythromycin & $15 \mu g$ & $\geq 21$ & $16-20$ & $\leq 15$ & $\leq 0.25$ & 0.5 & $\geq 1$ \\
\hline Clindamycin & $2 \mu g$ & $\geq 19$ & $16-18$ & $\leq 15$ & $\leq 0.25$ & 0.5 & $\geq 1$ \\
\hline
\end{tabular}

Table 2. D-Test results and possible phenotypes for Erytromycin (ERI) and Clindamycin (CLI) disks.

\begin{tabular}{|c|c|c|c|c|c|}
\hline \multicolumn{2}{|c|}{ DISKS } & \multirow{2}{*}{ D-TEST ${ }^{*}$} & \multirow{2}{*}{ PHENOTYPE } & \multicolumn{2}{|c|}{ REPORT } \\
\hline ERI & CLI & & & ERI & CLI \\
\hline $\mathrm{R}^{* *}$ & $\mathrm{R}$ & NEG & $\mathrm{cMLS}_{\mathrm{B}}$ & $\mathrm{R}$ & $\mathrm{R}$ \\
\hline $\mathrm{R}$ & $\mathrm{S}^{* * *}$ & POS & $\mathrm{iMLS}_{\mathrm{B}}$ & $\mathrm{R}$ & $\mathrm{R}$ \\
\hline $\mathrm{R}$ & $\mathrm{S}$ & NEG & M & $\mathrm{R}$ & $\mathrm{S}$ \\
\hline
\end{tabular}

${ }^{*}$ D-test results: NEG = Negative; POS = Positive; ${ }^{* *} \mathrm{R}=$ Resistent; ${ }^{* * *} \mathrm{~S}=$ Susceptible. 
The primers used are listed in Table 3. Their sequences were checked against the GenBank and synthesized by Operon Molecules for Life (USA).

For resistance genes, positive controls transferred by the Institute of Reference in Argentina "Dr. Carlos G. Malbrán" were used (National Institute of Infectious Diseases-ANLIS): Streptococcus pneumoniae AZ1 to ermB and mefA genes [31] and Streptococcus agalactiae 6394 to ermTR gene [32].

To confirm specificity, the PCR products for $b c a, b a c, \operatorname{lmb}$ and hylB virulence genes were sent and sequenced by Invitrogen and for the rib gene by the Sequencing and Genotyping Service of the National University of Buenos Aires. Reported sequences were analyzed by the program BlastX.

\section{Results}

5.5\%, eleven 200 isolates studied were serotype IX.

\subsection{Antimicrobial Susceptibility Testing}

As shown in Table 4 and Table 5 respectively, the eleven strains were susceptible to CLI and ERI (Figure 1(a))

Table 3. Sequence of primers used in PCR to amplify the virulence and resistance genes in isolates of Streptococcus agalactiae.

\begin{tabular}{cllc}
\hline Genes & \multicolumn{1}{c}{ Forward 5'-3' } & \multicolumn{1}{c}{ Reverse 5'-3' } & GenBank \\
\hline$e r m B$ & GAAAAAGTACTCAACCAAATA & AGTAATGGTACTTAAATTGTTTAC & DQ355148.1 \\
ermTR & TTGGGTCAGGAAAAGGA & GGGTGAAAATATGCTCG & AF00216.1 \\
$m e f A$ & GGTATCTTTAATCACTAGTGC & TTCTTCTGGTACTAAAAG & DQ445272.1 \\
bac & TGTAAAGGACGATAGTGTGAAGAC & CATTTGTGATTCCCTTTTGC & AB221536.1 \\
$b c a$ & CAGGAAGGGGAAACAACAGTAC & GTATCCTTTGATCCATCTGGATACG & M97256.1 \\
$r i b$ & CAGGAAGTGCTGTTACGTTAAAC & CGTCCCATTTAGGGTCTTCC & U58333.1 \\
hylB & TTATCATCCAGCGCCTCCTAG & GTGGTGATAACTGACTTCTTGGGA & Y15903.1 \\
$l m b$ & GACGCAACACACGGCAT & TGATAGAGCACTTCCAAATTTG & AF062533.1 \\
\hline
\end{tabular}

Table 4. Kirby-Bauer double-disk diffusion method on Mueller Hinton agar (Biokar, France), supplemented with 5\% of sheep blood, D-test and phenotype in Streptococcus agalactiae serotype IX.

\begin{tabular}{|c|c|c|c|c|c|c|c|}
\hline \multirow{2}{*}{$\mathrm{Nr}$} & \multirow{2}{*}{ SAMPLE ID } & \multicolumn{2}{|c|}{ DISKS $^{*}$} & \multirow{2}{*}{ D-TEST ${ }^{* *}$} & \multirow{2}{*}{ PHENOTYPE } & \multicolumn{2}{|c|}{ REPORT } \\
\hline & & Erythromycin & Clindamycin & & & Erythromycin & Clindamycin \\
\hline 1 & 16 & 28 & 34 & NEG & $\mathrm{N} / \mathrm{D}^{* * * *}$ & $\mathrm{~S}^{* * * *}$ & $\mathrm{~S}$ \\
\hline 2 & 1069 & 21 & 26 & NEG & N/D & $\mathrm{S}$ & $\mathrm{S}$ \\
\hline 3 & 1163 & 24 & 29 & NEG & $\mathrm{N} / \mathrm{D}$ & $\mathrm{S}$ & $\mathrm{S}$ \\
\hline 4 & 1167 & 23 & 26 & NEG & $\mathrm{N} / \mathrm{D}$ & $\mathrm{S}$ & $\mathrm{S}$ \\
\hline 5 & 3052 & 26 & 27 & NEG & $\mathrm{N} / \mathrm{D}$ & $\mathrm{S}$ & $\mathrm{S}$ \\
\hline 6 & 133 & 30 & 30 & NEG & N/D & $\mathrm{S}$ & $\mathrm{S}$ \\
\hline 7 & 156 & 22 & 22 & NEG & N/D & S & $\mathrm{S}$ \\
\hline 8 & 221 & 25 & 24 & NEG & N/D & S & S \\
\hline 9 & 264 & 24 & 23 & NEG & $\mathrm{N} / \mathrm{D}$ & S & S \\
\hline 10 & 248 & 25 & 23 & NEG & N/D & S & S \\
\hline 11 & 463 & 26 & 28 & NEG & N/D & $\mathrm{S}$ & $\mathrm{S}$ \\
\hline
\end{tabular}

${ }^{*}$ Diameter of inhibition in millimeters (mm); ${ }^{* *}$ D-test results: NEG = Negative; ${ }^{* * *} \mathrm{~N} / \mathrm{D}=$ Not Detected; ${ }^{* * * *} \mathrm{~S}=$ Susceptible. 
Table 5. E test for MIC determination for Erythromycin (ERI) and Clindamycin (CLI) in Streptococcus agalactiae serotype IX.

\begin{tabular}{|c|c|c|c|c|c|}
\hline \multirow{2}{*}{$\mathrm{Nr}$} & \multirow{2}{*}{ Sample ID } & \multicolumn{2}{|c|}{ MIC ( $\mu \mathrm{g} / \mathrm{ml})$} & \multicolumn{2}{|c|}{ REPORT } \\
\hline & & ERY & CLI & ERY & CLI \\
\hline 1 & 16 & 0.03 & 0.064 & $\mathrm{~S}^{*}$ & $\mathrm{~S}$ \\
\hline 2 & 1069 & 0.12 & 0.064 & $S$ & $\mathrm{~S}$ \\
\hline 3 & 1163 & 0.09 & 0.064 & S & S \\
\hline 4 & 1167 & 0.12 & 0.094 & S & S \\
\hline 5 & 3052 & 0.06 & 0.064 & S & S \\
\hline 6 & 133 & 0.12 & 0.094 & S & $\mathrm{S}$ \\
\hline 7 & 156 & 0.19 & 0.094 & S & S \\
\hline 8 & 221 & 0.12 & 0.047 & S & S \\
\hline 9 & 264 & 0.015 & 0.032 & S & $\mathrm{S}$ \\
\hline 10 & 248 & 0.12 & 0.190 & S & $\mathrm{S}$ \\
\hline 11 & 463 & 0.19 & 0.125 & S & S \\
\hline
\end{tabular}

${ }^{*} \mathrm{~S}=$ Susceptible.

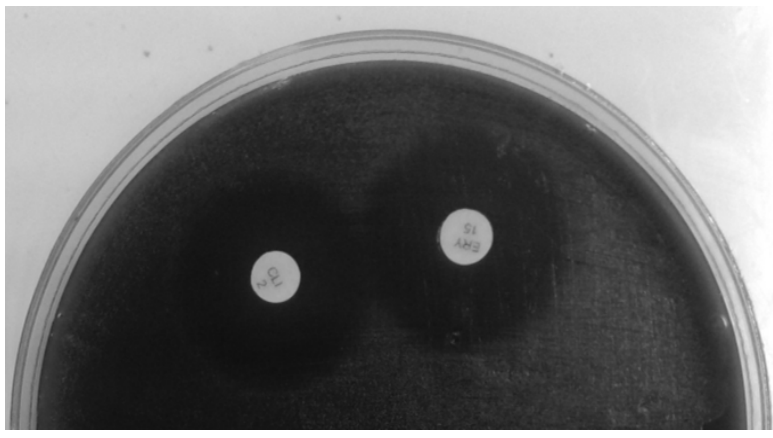

(a)

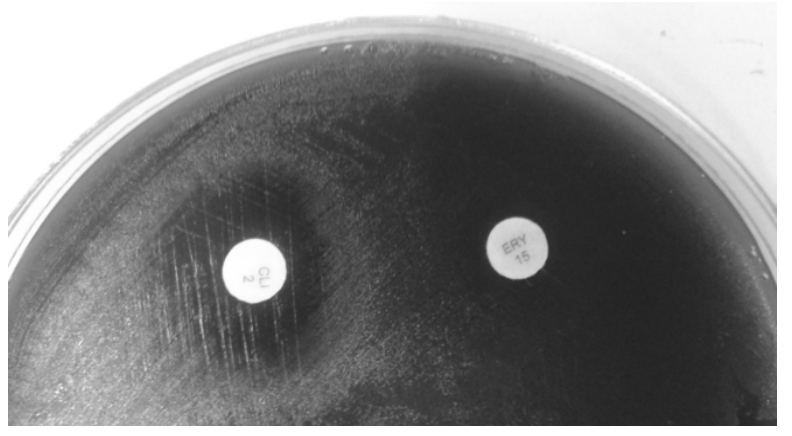

(b)

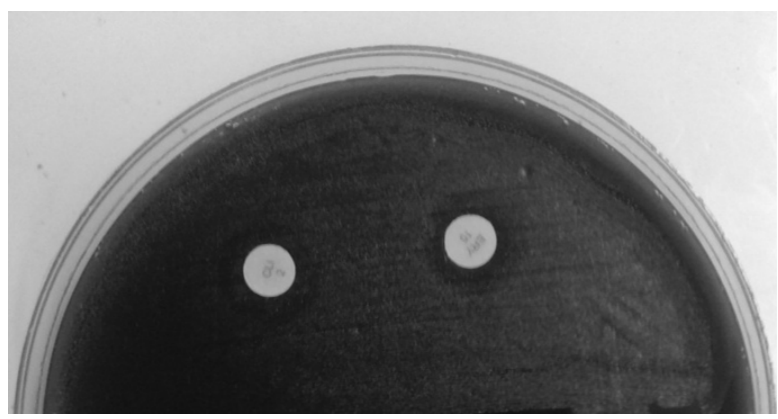

(c)

Figure 1. Kirby-Bauer double-disk diffusion method on Mueller Hinton agar (Biokar, France), supplemented with 5\% of sheep blood; (a) Erythromycin and Clindamycin susceptible, diameter of inhibition $\geq 21 \mathrm{~mm}$, D-test negative; (b) Erythromycin and Clindamycin resistant (clinical report), D-test positive (phenotype $\mathrm{iMLS}_{\mathrm{B}}$ ); (c) Erythromycin and Clindamycin resistant (clinical report), diameter of inhibition $\leq 20 \mathrm{~mm}$, D-test negative (phenotype $\left.\mathrm{cMLS}_{\mathrm{B}}\right)$. Erythromycin $(15 \mu \mathrm{g})$ and Clindamycin $(2 \mu \mathrm{g})$, disks used in the diffusion methods, were provided by Britania (Argentina).

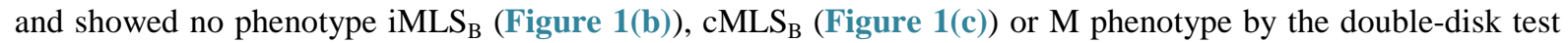
and the Etest for MIC determination yielded identical results obtained for ERI (Figure 2(a)), values in a range from 0.015 to $0.19 \mu \mathrm{g} / \mathrm{ml}$ and 0.032 to $0.19 \mu \mathrm{g} / \mathrm{ml}$ for CLI (Figure 2(b)). 


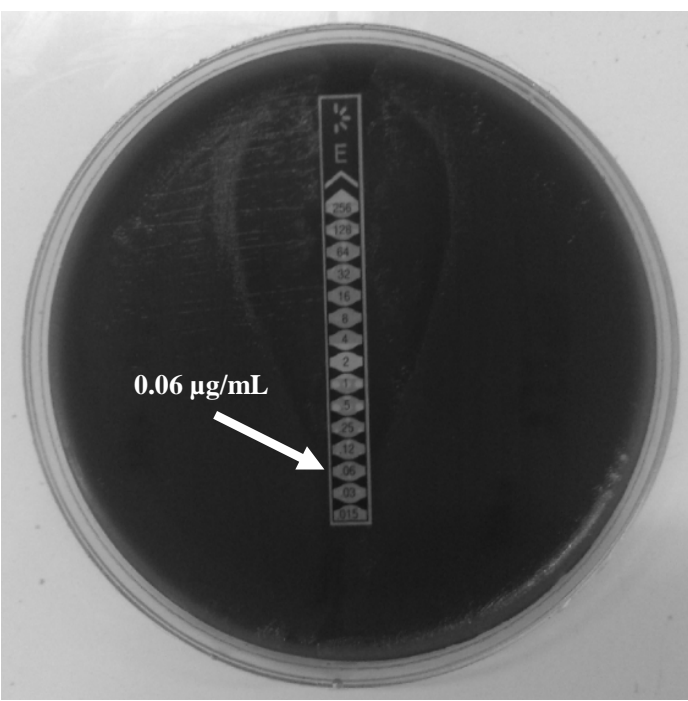

(a)

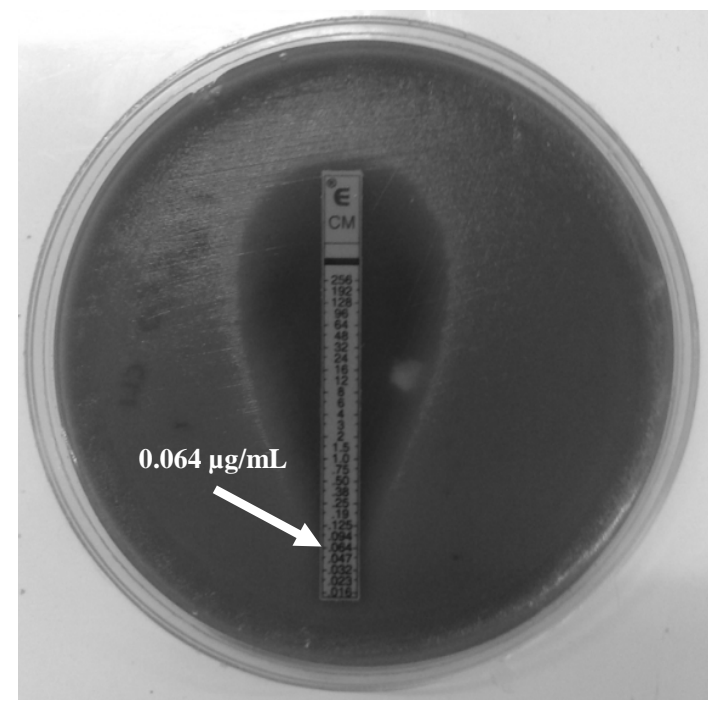

(b)

Figure 2. E test for Minimum Inhibitory Concentration (MIC) determination for Erythromycin (ERI) and Clindamycin (CLI) in GBS serotype IX (a) ERI MIC; (b) CLI MIC. The strips used in this determination were provided by (a) OXOID (United Kingdom) and (b) Biomeriux (France).

\subsection{Genetic Characterization}

Seven isolates showed three or more of the virulence genes studied ( 3 with 5 genes, 3 with 4 genes and 1 with 3 genes). In $63.6 \%$ of the strains the presence of the bac, bca and hylB genes was determined, and in $54.5 \%$ of $\operatorname{lmb}$ and rib. All genes were detected in different combinations, except from one strain in which only the presence of the $r i b$ gene was detected (Figure 3).

Five isolates showed the ermB gene, two of which also had the ermTR and mefA, genes were found only in those strains. In six of the studied strains the presence of the resistance genes was not detected (Figure 4).

The results obtained by DNA sequencing of the PCR products of genes bca, bac, Imb, rib and hylB, provided $99 \%$ similarity with the original sequence.

\section{Discussion}

In this work, we study the first isolations and molecular profiles of virulence and resistance to macrolides of GBS serotype IX in our country. In local, national and international literature there are no data available about carrying virulence genes, distribution, frequency and antimicrobial susceptibility of GBS serotype IX, thus exempting us from making comparisons of these early findings in Argentina in order to give scientific support to the hypothesis of a distribution of serotypes and fenotypes of circulation within a particular region and provide the knowledge for the development of valid vaccination strategies [12].

Geographical, temporal and ethnic variation shave been described in the distribution of capsular serotypes of GBS strains. Epidemiological surveillance of serotype distribution in a given region is important to the design of vaccines for prevention [13].

A feature of the strains of GBS is that the most virulence-associated genes encode proteins necessary for cell interaction host bacteria and pathogenicity [2] [5]. The antigens of the surface proteins and the genes that encode them are considered important for epidemiological characterization of the strains [21], for example, the alpha protein associated with the adhesion is encoded by the gene $b c a$ and $\beta$-protein involved in the invasion by the gene bac [15], the rib protein is encoded by the gene of the same name and is part of the complex c protein expressed in most invasive strains [33], the hylB protein encoded by the gene hylB, collaborates in dissemination and $\mathrm{lmb}$ protein encoded by gene $\mathrm{lmb}$, mediates in the adherence to human laminin [34]. The frequency of these proteins and the genes that encode them vary according to the origin of the strains (colonizing or invasive), study time, geographical area and type of population.

In our country GBS remains susceptible to penicillin, without any resistant strain described so far. Not so with 


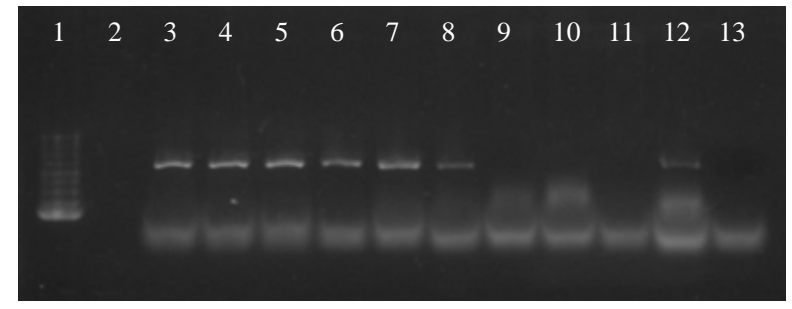

(a)

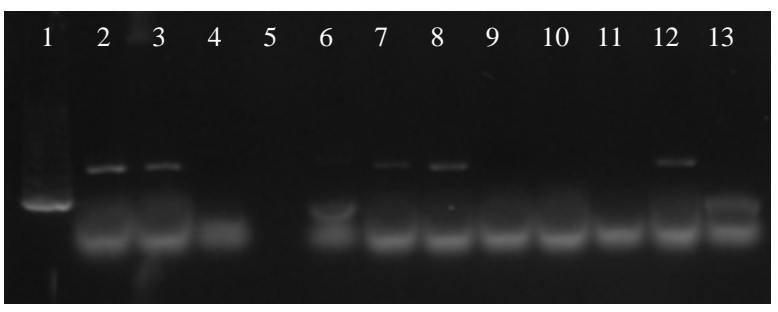

(c)

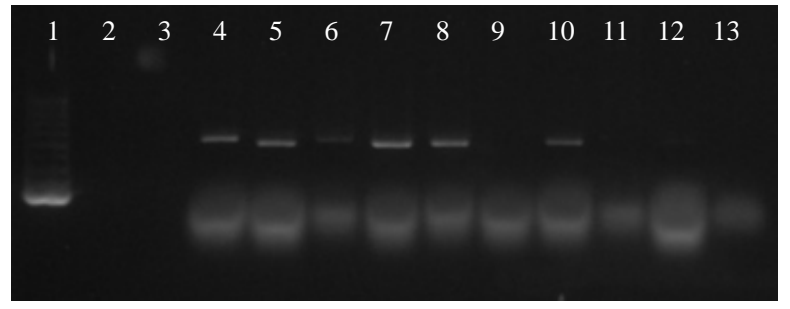

(b)

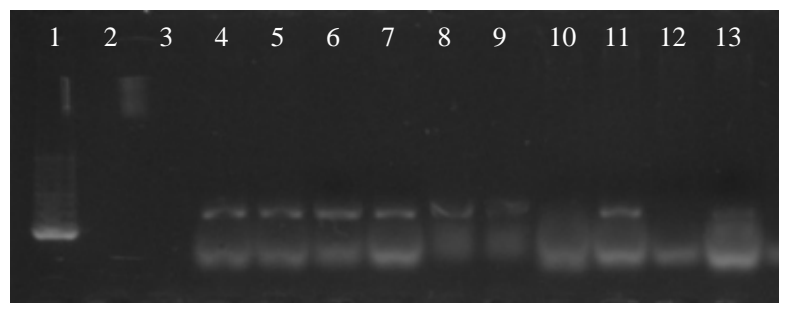

(d)

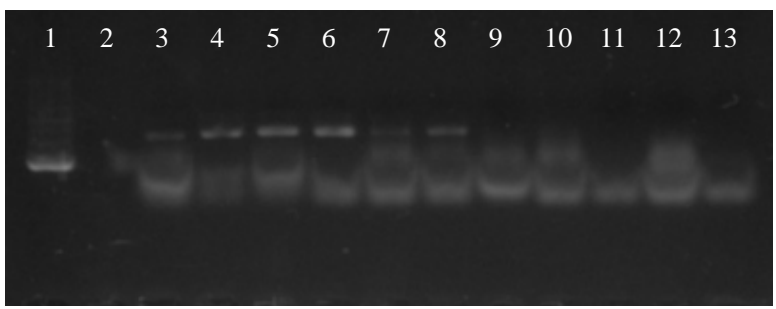

(e)

Figure 3. Electrophoresis in agarose gel $2 \%$ of PCR products for gene (a) bca, (b) bac, (c) rib, (d) hylB and (e) Imb. First lane, molecular weight marker, K562 DNA Molecular Weight [10 ng/ul] Promega Madison, Wi USA-lane 2 to 12, strains serotype IX: 16, 1069, 1163, 1167, 221, 264, 3052, 156, 133, 248, 463-last lane, negative control.

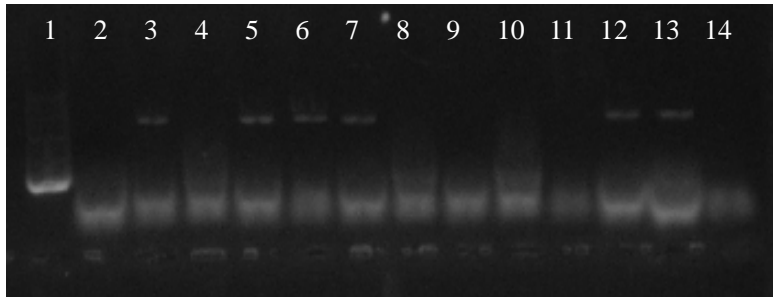

(a)

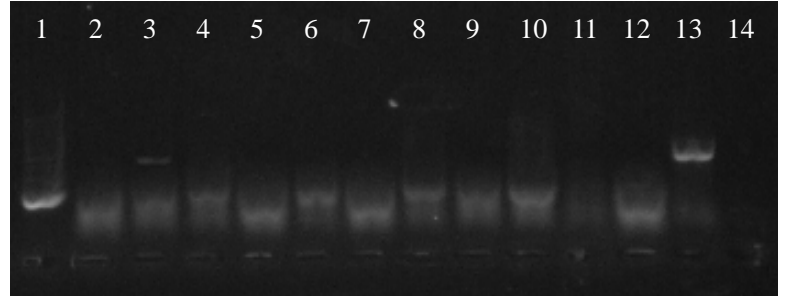

(b)

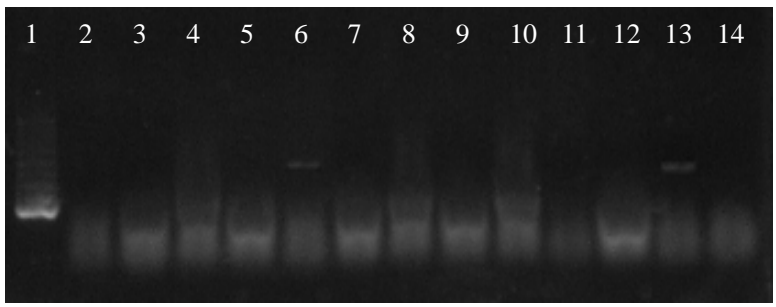

(c)

Figure 4. Electrophoresis in agarose gel 2\% of PCR products for gene (a) ermB, (b) ermTR, (c) mefA. First lane, molecular weight marker, K562 DNA Molecular Weight [10 ng/ul] Promega Madison, Wi USA-lane 2 to 12, strains serotype IX: 16, 1069, 1163, 1167, 221, 264, 3052, 156, 133, 248, 463-lane 13, positive control (Streptococcus pneumoniae AZ1 to ermB and mefA genes, Streptococcus agalactiae 6394 to ermTR gene), last lane, negative control. 
macrolide and lincosamides antibiotics groups. The emergence of strains resistant to erythromycin (ERI) and clindamycin (CLI), recommended for patients who are allergic to beta-lactam antibiotics, is already known, and the emergence of those strains also have geographic and ethnic variations. The values of resistance to macrolides and lincosamides vary between countries and even within the same country regionally, depending on the geographical area.

The data already published by the Chair of Bacteriology in our University [6] [16] [29] [35] share agreement with some argentinian authors and differ from others [36] [37].

While it is no purpose of this work to evaluate the frequency of resistant phenotypes ERY and CLI, it is important to highlight the figures in Misiones, Argentina where $\mathrm{CMLS}_{\mathrm{B}}$ phenotype is predominant in studies carried out in 100 colonizing GBS strains recovered from pregnant women who were at term in their gestational cycle [6].

Within the same country the results are different, which can be explained by the different policies applied on the use of antimicrobials in different regions.

Given the variability of data on the subject (even in our country), it is important to highlight the need of laboratories to have data about phenotypes of resistance to macrolides and lincosamides in all capsular types recovered in every pregnant patients colonized by SGB and allergic to penicillin.

Detection of resistance phenotypes will enable the choice of the antimicrobial to be used in the PIP, as one of the safest forms, pending availability of vaccines to prevent severe neonatal morbidity and mortality [19].

In agreement with other authors [6] [18] [19] and according to our results, we support the idea that sensitive strains may carry some of the resistance genes and can express them under certain as yet unknown environmental stimuli, especially GBS which already has the ability to acquire resistance genes from cervical-vaginal and rectal environment.

We can highlight that the serotype IX isolates studied were found only in colonizing strains which could indicate that it is less virulent than other serotypes that are directly linked to invasive neonatal disease as serotype III [38].

All strains were sensitive to ERI and CLI by the double-disk technique and confirmed by MIC, this may indicate that we are facing a serotype with low levels of resistance to these antibiotics in contrast to other serotypes as the well studied serotype $\mathrm{V}$ that is associated with high levels of resistance [39].

\section{Conclusions}

In conclusion, to know the antimicrobial susceptibility of all GBS isolates becomes necessary to assist in the proper and necessary prevention of severe neonatal disease with the introduction of PIP with appropriate antimicrobial.

The presence of serotype IX in Misiones and associated virulence genes encoding antigenic epitopes, places the region in a particular situation that could have impact on the vaccination strategy to be implemented in the future, as both serotypes circulating in a region and the virulence genes associated with production of specific antigenic proteins are fundamental to define it.

\section{References}

[1] Kilian, M. (2007) Streptococcus and Enterococcus. In: Greenwood, D., Slack, R., Peutherer, J. and Barer, M., Eds., Medical Microbiology, 17th Edition, Elsevier, Amsterdam, 178-193.

[2] Nobbs, A.H., Lamont, R.J. and Jenkinson, H.F. (2009) Streptococcus Adherence and Colonization. Microbiology and Molecular Biology Reviews, 73, 407-450. http://dx.doi.org/10.1128/MMBR.00014-09

[3] Fry, R.M. (1938) Fatal Infections by Haemolytic Streptococcus Group B. The Lancet, 1, 199-201. http://dx.doi.org/10.1016/S0140-6736(00)93202-1

[4] Larsen, J.W. and Sever, J.L. (2008) Group B Streptococcus and Pregnancy: A Review. American Journal of Obstetrics \& Gynecology, 198, 448-450. http://dx.doi.org/10.1016/j.ajog.2007.11.030

[5] Lindahl, G., Stalhammar-Carlemalm, M. and Areschoug, T. (2005) Surface Proteins of Streptococcus agalactiae and Related Proteins in Other Bacterial Pathogens. Clinical Microbiology Reviews, 18, 102-127. http://dx.doi.org/10.1128/CMR.18.1.102-127.2005

[6] Oviedo, P., Pegels, E., Laczeski, M., Quiroga, M. and Vergara, M. (2013) Phenotypic and Genotypic Characterization of Streptococcus agalactiae in Pregnant Women. First Study in a Province of Argentina. Brazilian Journal of Microbi- 
ology, 44, 253-258. http://dx.doi.org/10.1590/S1517-83822013005000030

[7] Schuchat, A. (1998) Epidemiology of Group B Streptococcal Disease in the United States: Shifting Paradigms. Clinical Microbiology Reviews, 11, 497-413.

[8] Hannoun, A., Shehab, M., Khairallah, M.T., Sabra, A., Abi-Rached, R., Bazi, T., et al. (2009) Correlation between Group B Streptococcal Genotypes, Their Antimicrobial Resistance Profiles, and Virulence Genes among Pregnant Women in Lebanon. International Journal of Microbiology, 2009, 1-6. http://dx.doi.org/10.1155/2009/796512

[9] Zhao, Z., Kong, F., Zeng, X., Gidding, H.F., Morgan, J. and Gilbert, G.L. (2008) Distribution of Genotypes and Antibiotic Resistance Genes among Invasive Streptococcus agalactiae (Group B Streptococcus) Isolates from Australasian Patients Belonging to Different Age Groups. Clinical Microbiology and Infection, 14, 260-267. http://dx.doi.org/10.1111/j.1469-0691.2007.01914.x

[10] Sadowy, E., Matynia, B. and Hryniewicz, W. (2010) Population Structure, Virulence Factors and Resistance Determinants of Invasive, Non-Invasive and Colonizing Streptococcus agalactiae in Poland. Journal of Antimicrobial Chemotherapy, 65, 1907-1914. http://dx.doi.org/10.1093/jac/dkq230

[11] Spellerberg, B. (2000) Pathogenesis of Neonatal Streptococcus agalactiae Infections. Microbes and Infection, 2, 17331742. http://dx.doi.org/10.1016/S1286-4579(00)01328-9

[12] Burns, G. and Plumb, J. (2013) GBS Public Awareness, Advocacy, and Prevention—What's Working, What's Not and Why We Need a Maternal GBS Vaccine. Vaccine, 31, D58-D65. http://dx.doi.org/10.1016/j.vaccine.2013.02.039

[13] Chen, V.L., Avci, F.Y. and Kasper, D.L. (2013) A Maternal Vaccine against Group B Streptococcus: Past, Present and Future. Vaccine, 31, D13-D19. http://dx.doi.org/10.1016/j.vaccine.2012.12.080

[14] Palmeiro, J.K., Dalla-Costa, L.M., Fracalanzza, S.E., Botelho, A.C., da Silva Nogueira, K., Scheffer, M.C., et al. (2010) Phenotypic and Genotypic Characterization of Group B Streptococcal Isolates in Southern Brazil. Journal of Clinical Microbiology, 48, 4397-4403. http://dx.doi.org/10.1128/JCM.00419-10

[15] Gherardi, G., Imperi, M., Baldassarri, L., Pataracchia, M., Alfarone, G., Recchia, S., et al. (2007) Molecular Epidemiology and Distribution of Serotypes, Surface Proteins, and Antibiotic Resistance among Group B Streptococci in Italy. Journal of Clinical Microbiology, 45, 2909-2916. http://dx.doi.org/10.1128/JCM.00999-07

[16] Laczeski, M., Pegels, E., Oviedo, P., Quiroga, M. and Vergara, M. (2013) Streptococcus agalactiae, First Study in Misiones of Resistance Genes Associated with Capsular Serotypes. Revista de Ciencia y Tecnologia, 19, 66-72.

[17] Clinical and Laboratory Standards Institute (2013) Performance Standards for Antimicrobial Susceptibility Testing. 16th Informational Supplement, 33 (1), M100S23.

[18] Poyart, C., Réglier-Poupet, H., Tazi, A., Billoët, A., Dmytruk, N., Bidet, P., et al. (2008) Invasive Group B Streptococcal Infections in Infants, France. Emerging Infectious Disease, 14, 1647-1649. http://dx.doi.org/10.3201/eid1410.080185

[19] Patten, S., Vollman, A.R., Manning, S.D., Mucenski, M., Vidakovich, J. and Davies, H.D. (2006) Vaccination for Group B Streptococcus during Pregnancy: Attitudes and Concerns of Women and Health Care Providers. Social Science \& Medicine, 63, 347-358.

[20] Imperi, M., Pataracchia, M., Alfarone, G., Baldassarri, L., Orefici, G. and Creti, R. (2010) A Multiplex PCR Assay for the Direct Identification of the Capsular Type (Ia to IX) of Streptococcus agalactiae. Journal of Microbiological Methods, 80, 212-214. http://dx.doi.org/10.1016/j.mimet.2009.11.010

[21] Savoia, D., Gottimer, C., Crocilla, C. and Zucca, M. (2008) Streptococcus agalactiae in Pregnant Women: Phenotypic and Genotypic Characters. Journal of Infection, 56, 120-125. http://dx.doi.org/10.1016/j.jinf.2007.11.007

[22] Slotved, H.C., Kong, F., Lambertsen, L., Sauer, S. and Gilbert, G.L. (2007) Serotype IX, a Proposed New Streptococcus agalactiae Serotype. Journal of Clinical Microbiology, 45, 2929-2936. http://dx.doi.org/10.1128/JCM.00117-07

[23] Ueno, H., Yamamoto, Y., Yamamichi, A., Kikuchi, K., Kobori, S. and Miyazaki, M. (2012) Characterization of Group B Streptococcus Isolated from Women in Saitama City, Japan. Japanese Journal of Infectious Diseases, 65, 516-521. http://dx.doi.org/10.7883/yoken.65.516

[24] Ferrieri, P., Lynfield, R., Creti, R. and Flores, A. (2013) Serotype IV and Invasive Group B Streptococcus Disease in Neonates, Minnesota, USA, 2000-2010. Emerging Infectious Diseases, 19, 551-558.

[25] Ippolito, D.L., James, W.A., Tinnemore, D., Huang, R.R., Dehart, M.J., Williams, J., et al. (2010) Group B Streptococcus Serotype Prevalence in Reproductive-Age Women at a Tertiary Care Military Medical Center Relative to Global Serotype Distribution. BMC Infectious Diseases, 10, 336. http://dx.doi.org/10.1186/1471-2334-10-336

[26] Rojo, P., Araya, P., Martínez, T.M.A., Hormazábal, J.C., Maldonado, A. and Fernández, J. (2008) Molecular Characterization of Chilean Isolates of Streptococcus agalactiae. Revista médica de Chile, 136, 606-612.

[27] Figueroa, J.R., Ibarra, F.J.O., Jaramillo, A.E. and Román, G.C. (2007) Maternal B Group Streptococcus Colonization in Mexico: Prevalence Based on Literature Review. Ginecología y Obstetricia de México, 75, 399-403. 
[28] Paoletti, L.J., Bradford, J. and Paoletti, L.C. (1999) A Serotype VIII Strain among Colonizing Group B Streptococcal Isolates in Boston, Massachusetts. Journal of Clinical Microbiology, 37, 3759-3760.

[29] Quiroga, M., Pegels, E., Oivedo, P., Laczeski, M. and Marta, V. (2011) Antimicrobial Susceptibility of Streptococcus agalactiae Isolated from Pregnant Women in Misiones, Argentina. In: Méndez-Vilas, A., Ed., Science against Microbial Pathogens: Communicating Current Research and Technological Advances, Formatex Research Center, Badajoz, 444-447.

[30] Sambrook, J. and Rusell, D.W. (2001) Molecular Cloning: A Laboratory Manual. Cold Sprong Harbor, New York.

[31] Corso, A., Faccone, D., Gagetti, P., Pace, J., Regueira, M., Pace, J., et al. (2009) Prevalence of mef and ermB Genes in Invasive Pediatric Erythromycin-Resistant Streptococcus pneumoniae Isolates from Argentina. Revista Argentina de Microbiología, 41, 29-33.

[32] Faccone, D., Lalonardi, F., Abel, S., Machain, M., Errecalde, L., Littvik, A., et al. (2010) Multiple-Clones of Streptococcus agalactiae Harbouring InuB Gene. Journal of Infection in Developing Countries, 4, 580-582.

[33] Persson, E., Berg, S., Bevanger, L., Bergh, K., Valsö-Lyng, R. and Trollfors, B. (2008) Characterisation of Invasive Group B Streptococci Based on Investigation of Surface Proteins and Genes Encoding Surface Proteins. Clinical Microbiology and Infection, 14, 66-73. http://dx.doi.org/10.1111/j.1469-0691.2007.01877.x

[34] Broughton, R.A. and Baker, C.J. (1983) Role of Adherence in the Pathogenesis of Neonatal Group B Streptococcal Infection. Infection and Immunity, 39, 837-843.

[35] Quiroga, M., Pegels, E., Oviedo, P., Pereyra, E. and Vergara, M. (2008) Antibiotic Susceptibility Patterns and Prevalence of Group B Streptococcus Isolated from Pregnant Women in Misiones, Argentina. Brazilian Journal of Microbiology, 39, 245-250. http://dx.doi.org/10.1590/S1517-83822008000200009

[36] Faccone, D., Guerriero, L., Méndez, E., Errecalde, L., Cano, H., Yoyas, N., et al. (2010) Fluoroquinolone-Resistant Streptococcus agalactiae Isolates from Argentina. Revista Argentina de Microbiología, 42, 203-207.

[37] García, S.D., Eliseth, M.C., Lazzo, M.J., Copolillo, E., Barata, A.D., de Torres, R., et al. (2003) Group B Streptococcus Carriers among Pregnant Women. Revista Argentina de Microbiología, 35, 183-187.

[38] Fleming, K.E., Bohnsack, J.F., Palacios, G.C., Takahashi S. and Adderson, E.E. (2004) Equivalence of High-Virulence Clonotypes of Serotype III Group B Streptococcus agalactiae (GBS). Journal of Medical Microbiology, 53, 505-508. http://dx.doi.org/10.1099/jmm.0.05443-0

[39] von Both, U., Ruess, M., Mueller, U., Fluegge, K., Sander, A. and Berner, R. (2003) A Serotype V Clone Is Predominant among Erythromycin-Resistant Streptococcus agalactiae Isolates in a Southwestern Region of Germany. Journal of Clinical Microbiology, 41, 2166-2169. http://dx.doi.org/10.1128/JCM.41.5.2166-2169.2003 
Scientific Research Publishing (SCIRP) is one of the largest Open Access journal publishers. It is currently publishing more than 200 open access, online, peer-reviewed journals covering a wide range of academic disciplines. SCIRP serves the worldwide academic communities and contributes to the progress and application of science with its publication.

Other selected journals from SCIRP are listed as below. Submit your manuscript to us via either submit@scirp.org or Online Submission Portal.
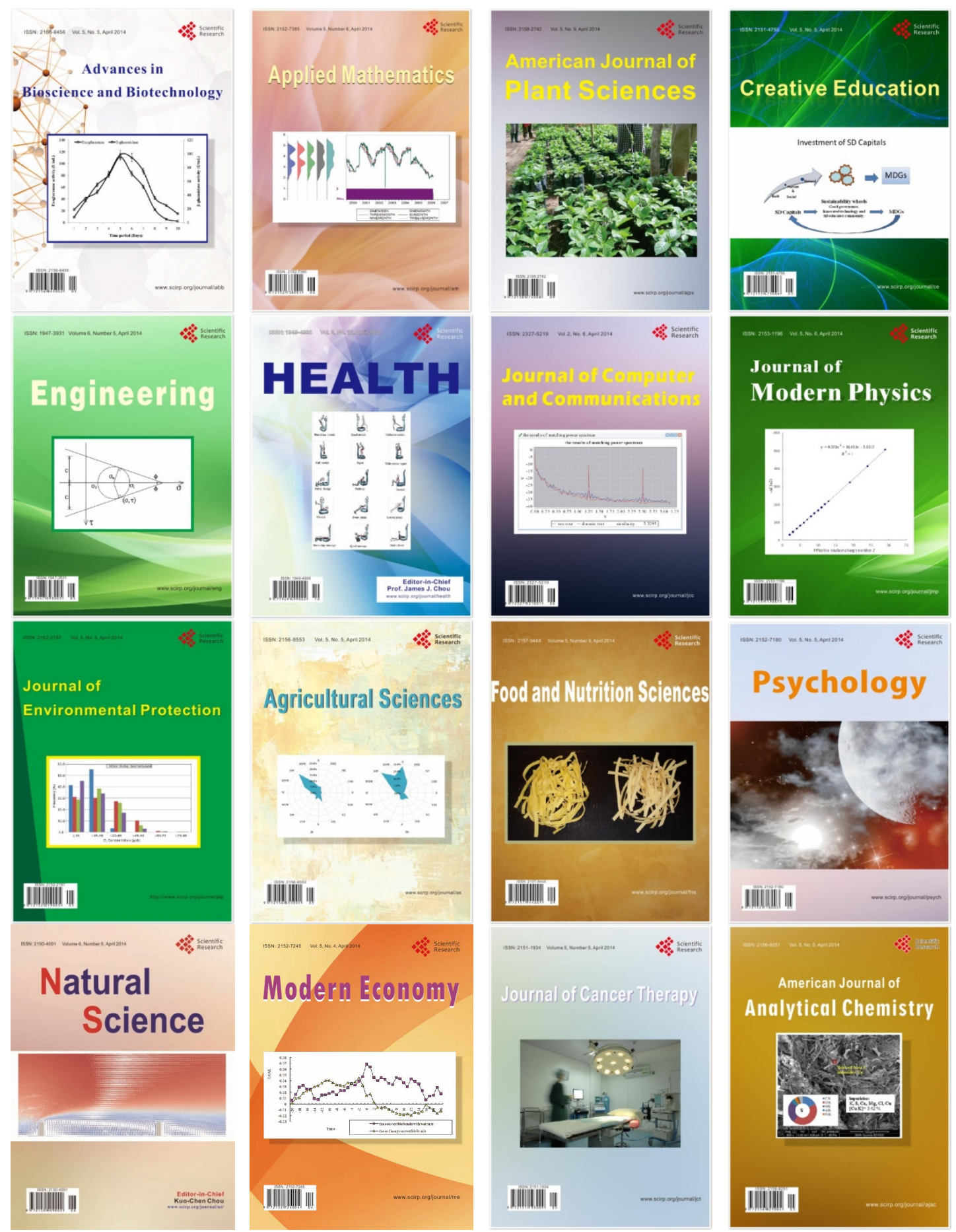